\title{
FROM CALCULATING MACHINES TO COMPUTERS AND THEIR ADOPTION BY THE MEDICAL SCIENCES
}

by

\author{
MARY A. B. BRAZIER*
}

\begin{abstract}
What shall we think of an engine of wood and metal which can not only compute astronomical and navigation tables to any given extent, but render the exactitude of its operations mathematically certain through its power of correcting its possible errors? What shall we think of a machine which can not only accomplish all this, but actually print off its elaborate results, when obtained, without the slightest intervention of the intellect of man?
\end{abstract}

Edgar Allan Poe, Southern Literary Messenger, April 1836, p. 319.

DowN THE years there has been a tradition of regarding biology, the biomedical sciences, and the behavioural sciences in general, as belonging to a class of endeavour widely different from that of technology, yet when one explores the history of these biosciences one finds how dependent their development has been on technological achievements. A plethora of examples could be given and the history of many has been traced.

In this paper one specific technology will be followed in its development, namely that of computers and the history of their entry into the armamentarium of those who research on the nervous system.

The biological sciences in comparison with other disciplines came rather late in their demand for the help that computers can bring as, in fact, they had come late to the urge to quantify their results in any way more complex than could have been achieved on the first calculating machine to be invented.

We have a description of the intellectual effort that went into that first calculating machine. It reads as follows:

If you sometimes think of inventing these machines, I should not have much difficulty in persuading you that the form of this instrument and its present state is not the outcome of my first idea. I began the project with a totally different machine from this one, both in material and form which (although it pleased many) did not entirely satisfy me. In the course of changing it little by little I imperceptibly created a second. In this again I found inconveniences which I could not put up with and in order to remedy them I designed a third which is very simple in its construction ... All the same, always seeking to perfect it, I made more than 50 different models before accomplishing the machine which $I$ have made now. ${ }^{20}$

In Figure 1 is one of the machines this inventor was discussing and the inventor was Pascal. He started work on his first design in 1642 at the age of nineteen, demonstrated a model to Henry II of Bourbon in 1644 and produced the final model in 1652.1, There are eight of Pascal's 'machines de calcul' still in existence. (For a scholarly study of each of these machines see Payen, ref. 30.)

Legend has it that in 1647 he demonstrated an early model to Descartes but the

*The work of this investigator is supported by Career Research Award 5K06 NS 18608 from the National Institutes of Health and Grant NS 11379 from USPHS. 


\section{Mary A. B. Brazier}

contemporary sources (including Descartes' own letters') indicate that it was Pascal's experiments on atmospheric pressure that were discussed by these two giants rather than calculating machines.

Much later, after his conversion to Janssenism, Pascal, writing his 'Pensées', bitterly attacked Descartes, accusing him of a flippancy by which he was able to by-pass the Deity in his philosophy. 'Je ne puis pardonner à Descartes: Il aurait bien voulu, dans toute sa philosophie, pouvoir se passer de Dieu; mais il n'a pu s'empêcher de lui faire donner une chiquenaude, pour mettre le monde en mouvement; après cela, il n'a plus que faire de Dieu'. Pensées, published posthumously, Port-Royal 1669. (Ref. 31).

Pascal sent one of the final models to Queen Christina of Sweden in 1652, but when she abdicated this was secretly shipped out of the country and returned to Paris where it has disappeared without a trace. ${ }^{27}$ Four of his models can be seen at the Conservatoire des Arts et Métiers in Paris (one of which may be a facsimile), the remainder being in provincial museums.

These calculating machines of Pascal's no doubt seem very simple to the user of the modern computer for they could only add and subtract; multiplication or division had to be done by serial additions or subtraction (as on many of our desk calculators today). The next step, that of direct multiplication, was a very difficult one and more than 200 years were to pass before this was accomplished.

Pascal's first machine was not designed for science but to help his father who was a tax collector and this is why some of his instruments calculate in sols et deniers. ${ }^{17}$ This complicated the usual decimal system since there were twelve deniers to a sou. Another 300 years were to pass before the binary system was adopted for a computer.

The need, however, to achieve multiplication and division was very great in spite of the laborious serial procedures entailed. These were deemed of sufficient importance to be given in detail for Pascal's machine in Diderot's Encyclopédie ${ }^{8}$ nearly a century after his death.

An early description of the operation of one of these machines was also published in 1735 by Martin ${ }^{24}$ but in Pascal's lifetime the only really detailed description (other than his own) was that written by Charles Belair in reponse to the expressed wish of Christiaan Huygens ${ }^{18}$ to borrow one of Pascal's calculating machines in 1659. Huygens returned this instrument to France on the occasion of Pascal's death in 1662 but this model (which could accomplish only addition) has since disappeared.

Pascal, the first inventor of a surviving calculating machine met the same absurd comment that later generations had to face, namely that his instrument was a mechanical brain. ${ }^{17}$ Just as, three centuries later, computer scientists had to make the point to their critics, so Pascal made clear that his machine merely did what it was told and did not initiate a mental process. He pointed out that it surpassed the lower animals in being able to effect calculations but fell short of them by lack of operations of the will. 'La machine arithmétique fait des effets qui approchent plus de la pensée que toute ce que font les animaux: mais elle ne fait rien qui puisse faire dire qu'elle a de la volonté, comme les animaux.' Pensées, ref. 31.

As so frequently happens in science, when the time becomes ripe for a leap forward, similar ideas may occur independently to workers unaware of each other's inventions. 


\section{From Calculating Machines to Computers}

A striking example came to light in 1958 with the finding in the correspondence of Kepler, preserved at the Observatory of Pulkovo outside Leningrad, of a letter ${ }^{10}$ from Wilhelm Schickhard, a seventeenth-century professor at the University of Tübingen written in 1624 to Kepler, describing a machine which he claimed could add, subtract and, by serial additions and subtractions, multiply and divide. The discovery of this letter sparked further research into Kepler's correspondence and this unearthed an earlier letter (1623)* that had in fact been published posthumously in $1718^{13}$ but went unnoticed at the time. Although the inventor had in mind the usefulness of his machine (of which he drew a sketch) for calculations in astronomy, there is no evidence that Kepler recognized its potential. He painstakingly calculated the orbits of the planets by logarithms and dedicated his work to 'the illustrious Baron Napier'.

There is no doubt of Schickard's design though there is no record of anyone but himself having seen the machine when constructed. In modern times examples have been built from this design, one in his native town of Tübingen and another modern copy is in the State Museum in Poland. At most there seems to have been only one original and that, Schickhard says (in his second letter) $\dagger$ was destroyed in a fire. There is no evidence of Pascal's ever having heard of it, or of its having inspired any later designer.

Several designers followed Pascal's lead in making instruments that achieved these (to us now) simple arithmetic steps, one of the most famous being Leibniz. ${ }^{22}$ Only one original of his exists (in the Niedersächsische Landesbibliothek in Hannover) and it is not entirely clear that a second was ever, in fact, constructed. However, his detailed description has survived and from this a model was made in 1923 for exhibition. The model is in the Deutsches Museum in Munich and, though faithful to his design, shows in its construction the inevitable signs of the modern metal worker's craftsmanship (figure 2).

Pascal put his machines on sale (for 100 livres) in 1645 and immediately became plagued by copiers who made inferior models which he felt were damaging to his design. In 1649, he was able to obtain a legal restraint against copiers (with a fine of 300 livres) but this can hardly compare with the protective patents taken out by modern computer designers.

In Pascal's own country, we find a magnificent designer in that many-sided genius, Claude Perrault, physician, zoologist, mathematician and architect of the colonnade on the east wing of the Louvre. For the bioscientist, Perrault is the first in this discipline to invent a calculating machine. Neurophysiologists remember him for his experiments on dogs in which he was a pioneer in studying the effect of cortical ablations. ${ }^{22}$

In the year of his death (1688) he brought out his 'machine à addition' which he called the 'Abaque rhabdologique', a design entirely independent of Pascal's, working as it does, on a system of sliding rulers. He died before he could construct more than

\footnotetext{
* Schickhard wrote to Kepler in a letter (original in Latin) dated 20 September 1623 as follows: 'Très illustré et excellent Maitre Képler ... j'ai conçu une machine composée de 11 roues complètes et de 6 roues mutilées; elle calcule à partir de nombres donnés d'une manière instantanée et automatique, car elle ajoute, retranche, multiplie et divise. Cela te divertirait fort . $\therefore$

fFor an account of the discovery of these letters and a description of Schickard's invention see the interesting articles by René Taton, refs. 43 and 44.
} 
this one model but it still exists at the Conservatoire des Arts et Métiers (figure 3), and the description of it was published posthumously. ${ }^{33,34}$

Pascal's invention certainly had an immediate impact for commercial users, though it was not applied in pure science. After his death several similar instruments were brought out in France; among those of which examples have survived are that of Lépine $^{23}$ (1725) and of Hillerin de Boistisandeau ${ }^{15}$ (1730). Many others followed, one of the most influential being the invention of Thomas, ${ }^{16} \mathrm{a}$ director of an insurance company in Colmar, for until the problem of actual mechanical multiplication was solved, Thomas' design of $1820^{45}$ was the basis of the majority of machines for commercial use and was one of the few early calculators (other than Pascal's) that progressed from a prototype to a series.

In England the first was Morland's arithmetic machine built in London in 1664 for commercial use. It is the opinion of scholars (for example, d'Ocagne ${ }^{28}$ ), that Morland was unaware of Pascal's machines, for in some ways his design is more primitive.

An original is in the Museum of the History of Science in Florence (figure 4); in appearance it is very similar to Pascal's though with more dials. However another design of Morland's in the Science Museum in London, is a triumph of compactness, measuring only 6 by 3 inches.

Morland wrote a description ${ }^{25}$ of two of his instruments for which he made the following claim: 'A new and most useful instrument for addition and subtraction of pounds, shillings and pence and farthings; without charging the memory, disturbing the mind, or exposing the operator to any uncertainty; which no method hitherto published, can justly pretend to.'

Morland also wrote a description ${ }^{26}$ of 'A new multiplying instrument' but one should not be misled by this title for the operation was for trigonometric multiplication of angles.

None of these instruments achieved multiplication and division except through serial additions and subtractions; not even the genius of Leibniz, the co-inventor of calculus, was able to take this giant step in calculating machines. And this in spite of his conviction (as he expressed it) that: 'It is unworthy of excellent men to lose hours like slaves in the labour of calculation which could safely be relegated to anyone else if machines were used.'

In 1839, a century and a half after Perrault, we find the interest coming once again from the field of medicine. In that year Dr. Didier Roth, ${ }^{36}$ a doctor of medicine, made a bold attempt to construct an ingenious machine that would multiply. Unfortunately the poor degree of precision in instrument-making at the time resulted in failure, though the capability of his machine for addition and subtraction was a great improvement over Pascal's

In fact, a gap of over 200 years lies between Pascal's machine and the first truly multiplying machine. This too came from France, made by Leon Bollée less than a century ago, ${ }^{5,38}$ patented there in 1889 . Two originals of slightly different design are in the Conservatoire des Arts et Métiers in Paris (figure 5), and one made from his design can be seen in the Smithsonian Museum in Washington (with a U.S. patent dated 1896). 


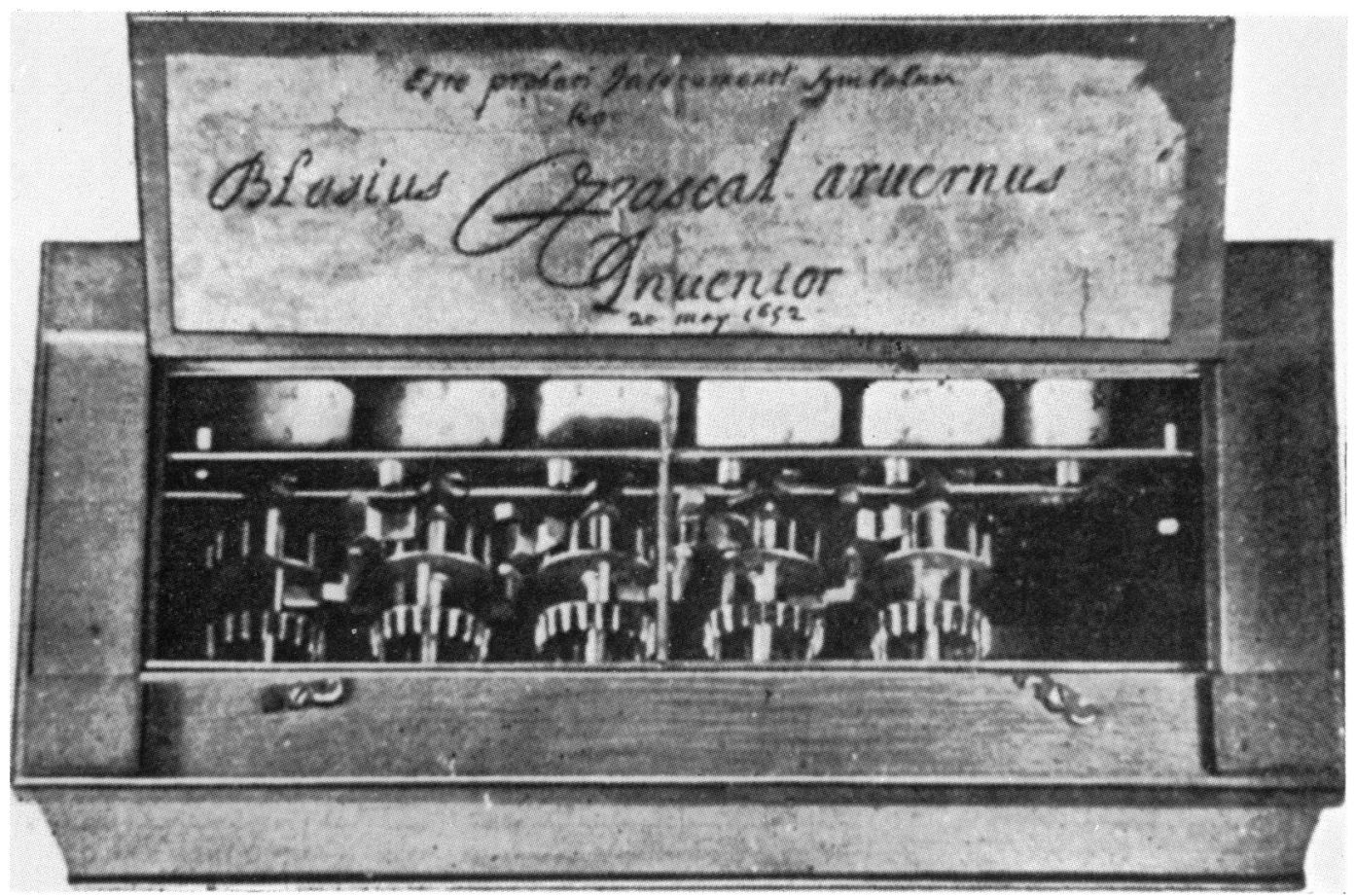

Figure 1

Pascal's machine. One of the authenticated examples, carrying inside the lid the inscription 'Esto probati Instrumenti Symbolum hoc. Blasius Pascal Aruernus Inventor, 20 May 1652'.

(No: 823-1 at the Conservatoire des Arts et Métiers. Paris.)

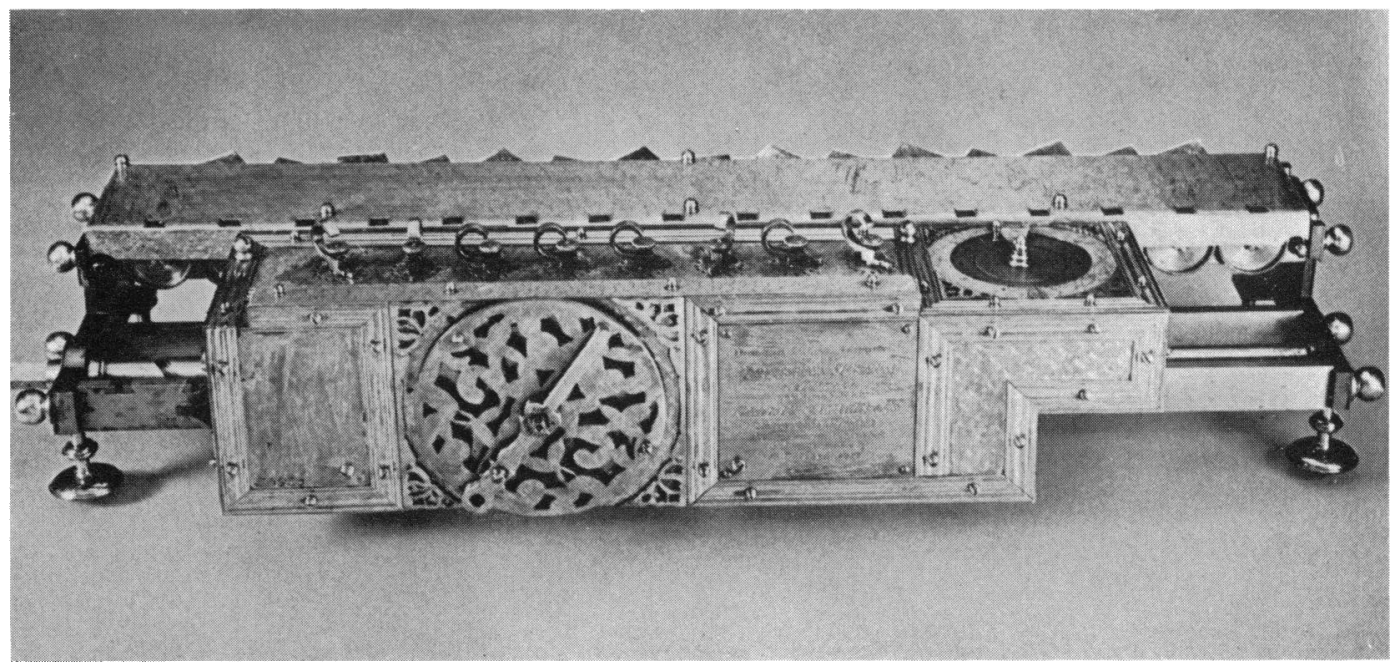

Figure 2

Copy, made in 1923 from the design of Leibniz 250 years later (Deutsches Museum in Munich). 


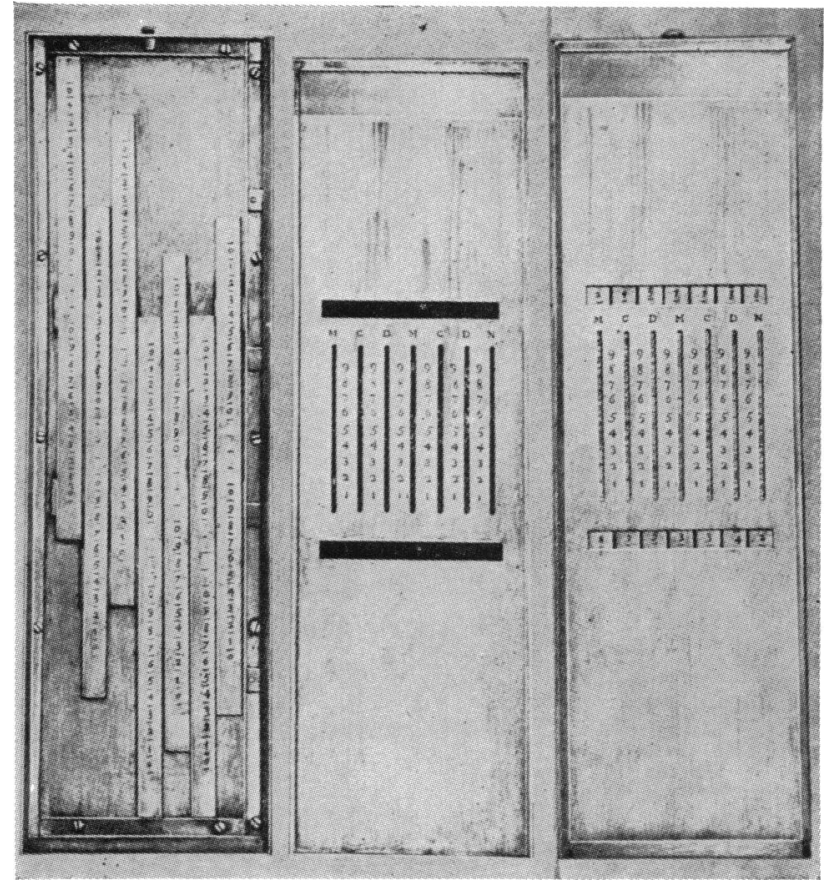

Figure 3

Perrault's 'Abaque Rhabdologique' for addition and subtraction 1688. (Preserved in the Conservatoire des Arts et Métiers. Paris.)

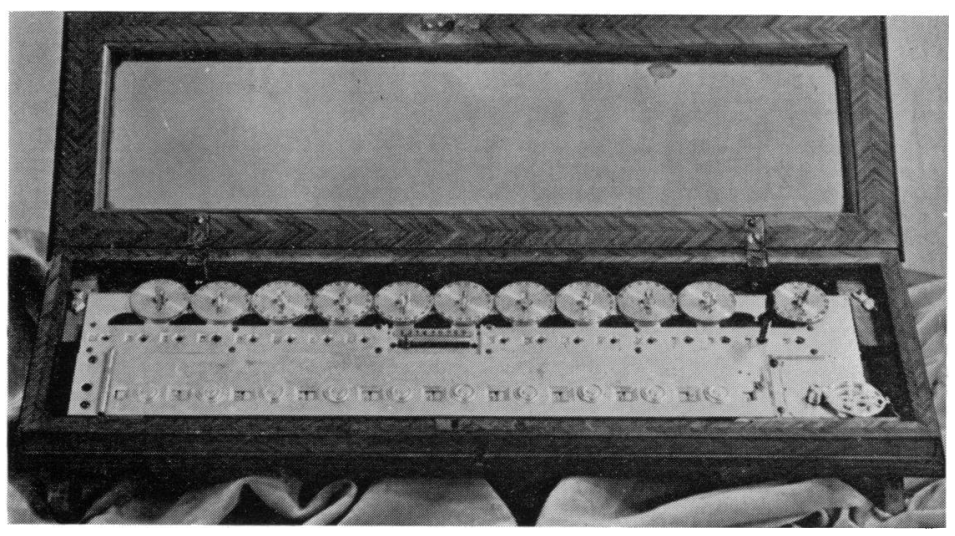

Figure 4

The first English arithmetic machine. Samuel Morland's calculator 1644. (Museum of the History of Science. Florence.) 


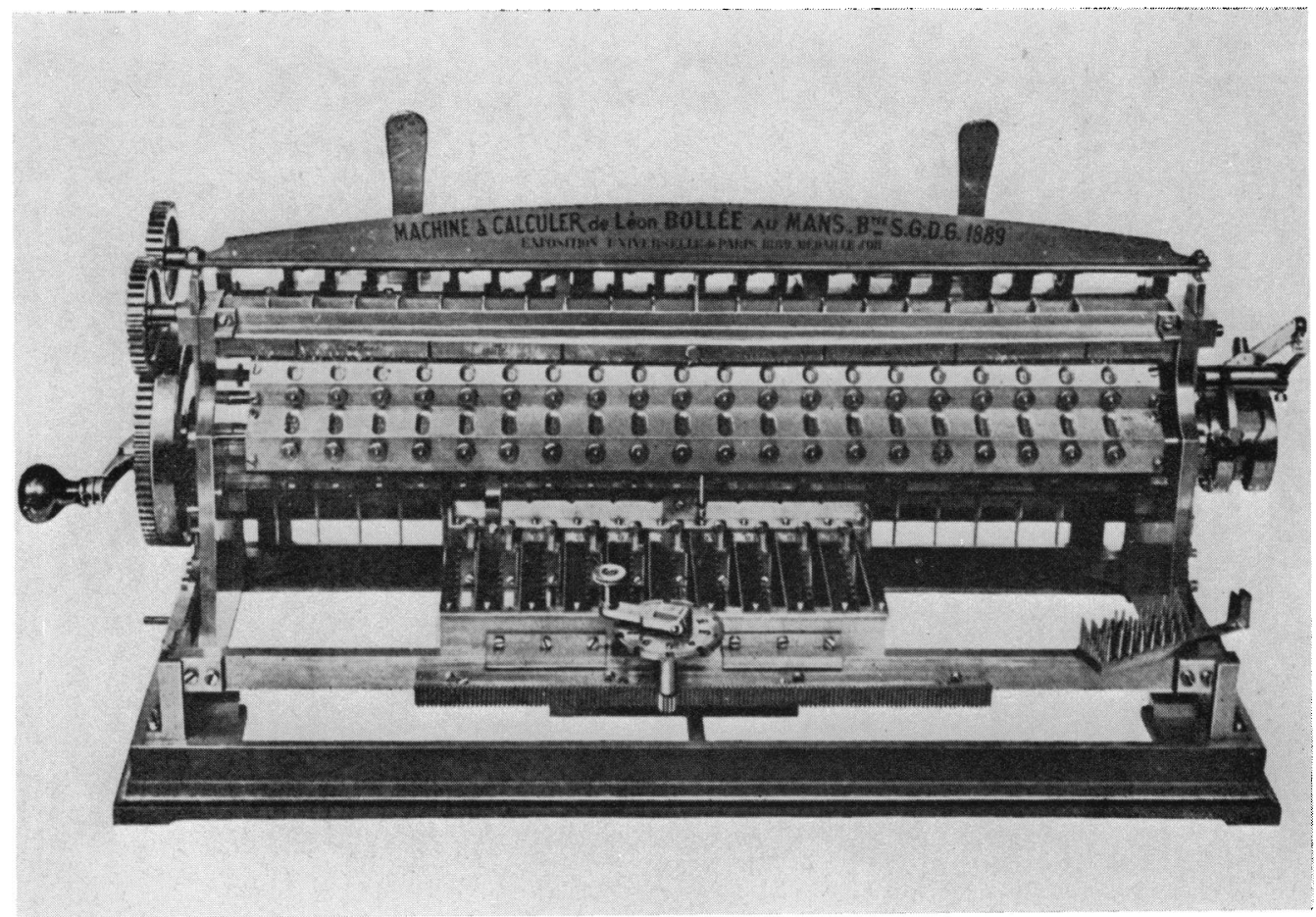

Figure 5

Leon Bollée's machine: The first true multiplier: Model of 1889.

(Conservatoire des Arts et Métiers. No. 11. 650).

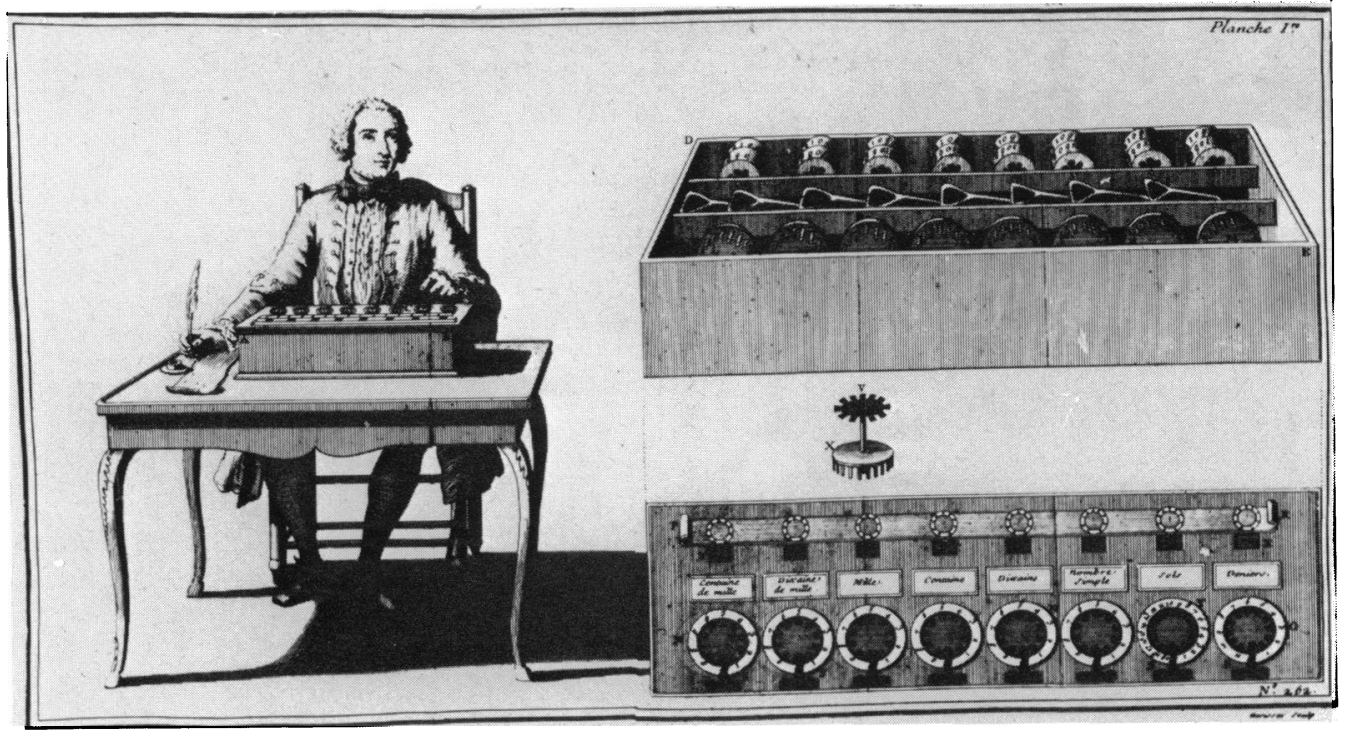

Figure 6

Manual operation of one of Pascal's machines. This depicts the one that belonged to the Périer family and donated to the Académie des Sciences in 1711. It is now in Conservatoire des Arts et Métiers. No. 823-3. (Sketch reproduced from: 'Machine Arithmétique de M. Pascal', Recueil des Machines approuvées par l'Academie, 1725, 4, 137-39. 

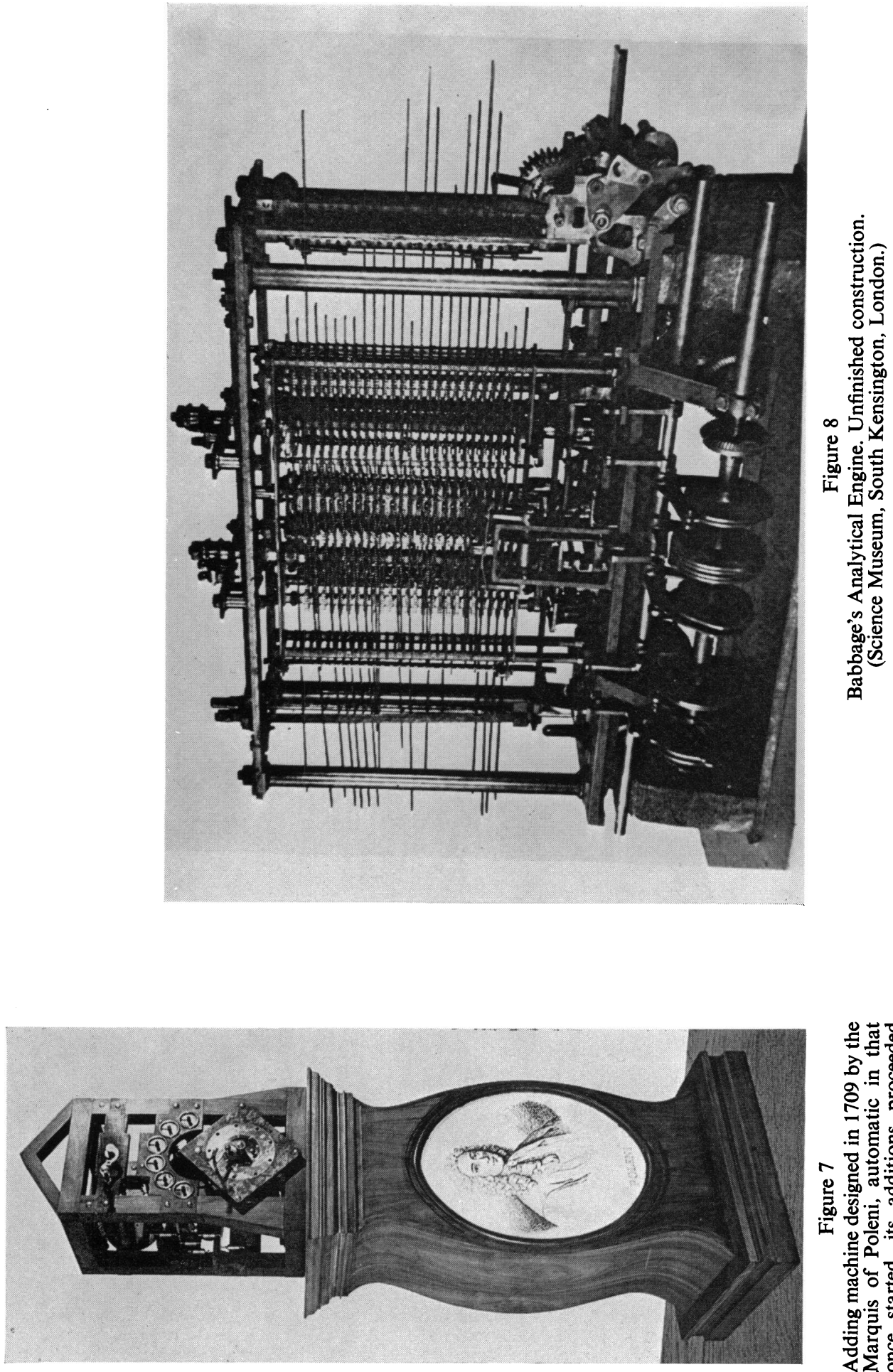

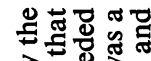

ते

응. 년윤.

.

- 它题:

은

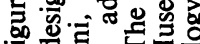

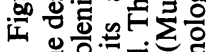

.

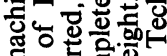

है.

कo. के

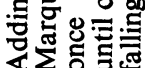




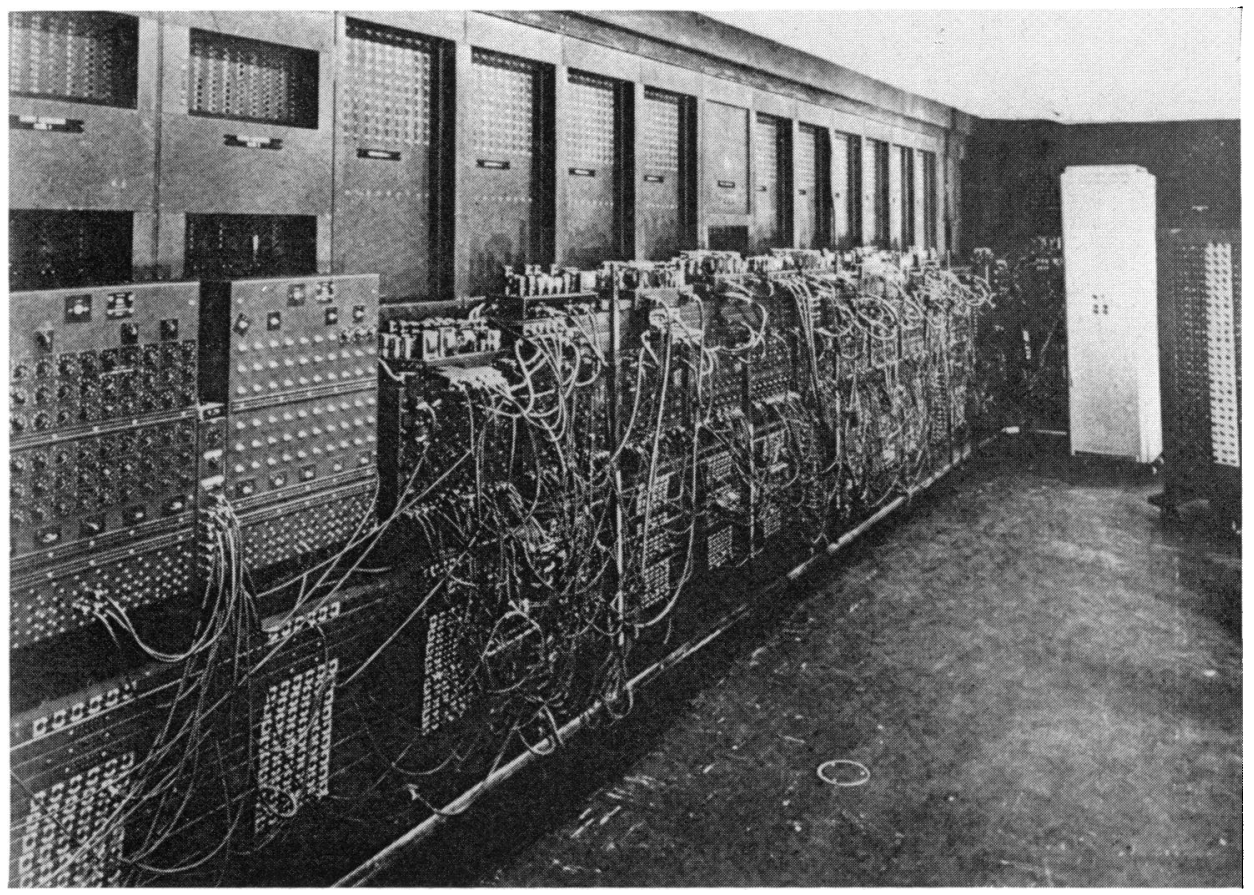

Figure 9

The age of the giant computer. ENIAC, the first wholly electronic computer 1946. 


\section{From Calculating Machines to Computers}

With this new capability, the calculating machine began to approach more closely to our modern ideas of a computer but electronics had not yet come to the aid of man, and all these earlier calculators were mechanical. It was not until the twentieth century that scientists could utilize the technological invention of the vacuum tube (Fleming, $1904^{10}$, Lee De Forest, 1906 ${ }^{21}$ ). Electromagnets were introduced by Selling ${ }^{39}$ into one of his later machines (1894) but this is as far as the meaning of an 'electrical' calculating machine went at that time.

It is not surprising that none of these ancestors of the modern computing machine was being used by bioscientists, for they had yet to recognize the place of measurement in their disciplines; they had no urge to quantify their phenomena. In this respect the principal leadership in the neurosciences came from Helmholtz ${ }^{14}$ in the last century. His measurement of the velocity of the nerve impulse is a landmark in the quantification of a biological event, but science had had to wait until 1850 for his achievement and was to wait an additional century before computer analysis could be used to refine it.

In the serial development of calculating machines we reach the end of the nineteenth century with their still being mechanical and still manually operated very much as they had been in Pascal's day (figure 6).

Automated machines came very late, although they have an ingenious ancestor from the first decade of the eighteenth century. In 1709, the Marquis of Poleni ${ }^{35}$ invented a machine driven by a falling weight which turned a triple cog wheel (for units, tens and hundreds)_each wheel with nine teeth. Slow and ponderous in operation, it was however charming in appearance (figure 7) and can be seen in the Museum of Science and Technology in Milan. For the single operation for which its dials could be set, it was truly free of manual control when once started and acted automatically until the weight hit bottom.

Leibniz envisaged, but did not construct, a motor-driven calculator, and credit for the first useful machine that was truly automated must apparently go to Abraham Stern $^{42}$ of Warsaw whose design, published in 1814 worked by clockwork.

By the end of the century there were scores of adding machines but it had taken two and a half centuries to improve very strikingly on the capability of Pascal's primitive invention except in the matter of speed. Slowly various features had been added: the ability to solve cube roots, to calculate 'differences' (for example for solution of differential equations) and now finally to multiply directly. A flurry of interest arose in 1814 caused by the report that Stern's machine could find prime numbers, but this proved to be an error by the translator from the Polish description.

And now at last we find scientists from other disciplines realizing that these instruments could be used in other ways than for counting money. In 1893 a conference was held at the Conservatoire des Arts et Métiers to publicize the resources that mechanical calculation could provide to the sciences. The attendance included engineers, mechanics, electricians, artillery experts, geodesians, financiers-but no biologists. History gives us the name of only two physicians in this field of endeavourPerrault in the seventeenth century and Roth in the nineteenth, who had the misfortune to go blind before he could finish the designs of his later models. The biologists also let pass by the era of Babbage's pioneer designs. 


\section{Mary A. B. Brazier}

Babbage ${ }^{2,3}$ never constructed his total design of the 'Difference Engine', although in 1822 he had made a miniature working model for demonstration in the hopes that the Government would finance the construction of commercially usable machines. This hope was never fully realized for, when twenty years later Babbage had still no finished computer, funds were cut off. This was no doubt partially because Babbage's fertile mind had in the meantime conceived of a far more capable machine: the Analytical Engine. In fact, only one fully completed difference machine was constructed for him in his life-time though he lived until 1871. A partially constructed one (which well illustrates the principles) can be seen at the Science Museum in London, as can also the skeleton of an Analytical Engine (figure 8).

The concepts of the Difference Engine did not however completely fade, for a Stockholm printer and his son (G. and E. Scheutz ${ }^{37}$ ) constructed one, essentially from Babbage's drawing, and this was exhibited in Paris in 1855. The original of this machine is in Albany, New York.

It was 300 years, rather than 200, after Pascal that anything approaching what we now understand by a computer cameinto being; even now computers are only in their third decade of general use. Their appearance was like that of a sudden mutant.

The advent of computers, even for military development, was not foreseen within a decade of their successful development. In the United States, the Director of Defense Research and Engineering, 11 testifying before the Senate Committee on Armed Services in 1969, said: 'Those who in the past have tried to predict the future of science have usually been far too conservative. For example, one technical forecast in 1937 missed computers, atomic energy, antibiotics, radar and jet propulsion.'

Yet within two years of that date, war came once again to the world, and during this time some extremely powerful instruments were designed and built in the secrecy that war unfortunately demands. It was therefore with explosive impact on those biologists not engaged in these classified programmes that the capabilities of the modern computer broke at the war's end. Vannevar Bush's analog computer at the Massachusetts Institute of Technology, Aiken's digital Mark I at Harvard (Automatic Sequence Controlled Calculator (1944). Ref. 41) begun in 1939 and operating in 1944, and the well-kept secret of ENIAC (Electronic Numerical Integrator and Calculator, 1946) at the Aberdeen Proving Ground (the first wholly electronic computer with its 19000 vacuum tubes) were, in the United States, the outstanding computers revealed at this time.

ENIAC, designed by Eckert and Mauchly, was a special-purpose computer in the sense that it performed a specific sequence of calculations and its circuits had to be rewired for any other sequence. Thus was introduced the era of the 'giant computer' and the investigator became used to roomfuls of bulky equipment which he could not, himself, operate.

The next great step was that of Von Neumann who introduced the concept of a general-purpose machine which could be instructed to carry out any sequence of operations capable of being formulated in numerical terms. He proposed that the orders to the machine be reduced to a numerical code, and thus the modern era of digital computing was opened.

It is generally thought that the invention of the binary system of numbering now 


\section{From Calculating Machines to Computers}

used was introduced by Boole but it has a far longer history, having been proposed and illustrated in the sixteenth century by Thomas Hariot (1560-1621). ${ }^{12}$

In the decade that followed the introduction of numerical coding, all computers were immensely expensive, not only to purchase or rent, but to run and maintain with their vast number of vacuum-tube components. By 1955 only twenty-five universities in the United States had installed computers and only a few scientists were experimenting in their laboratories with pilot models of non-commercial design.

In England, immediately after the war, intensive work had begun at the Telecommunications Research Establishment in Malvern on a computer design that later moved to Manchester University and achieved completion in 1948 as the famous MADM (Manchester Automatic Digital Machine, completed in 1951. Ref. 20.), to be followed some years later (in collaboration with Ferranti) by Atlas. At Cambridge the EDSAC (Electronic Delayed Storage Automatic Computer, completed in 1951. Ref. 48.) was in development and at the National Physical Laboratory at Teddington, the ACE (Automatic Calculating Engine, completed in 1957, Pilot Model, 1951.) inspired by Turing.

Computers were rather eagerly brought into the neurosciences for electrophysiologists had early developed a desire to quantify their recordings. The voltage-time curves of brain waves had for some time been explored by mathematicians ${ }^{9}$ in terms of Fourier analysis but the first automatic analyzer to become the prototype for the many commercial models that were to follow was that designed by Grey Walter ${ }^{46}$ during the war and before the public advent of computers.

In the 1940s, at the urging of Norbert Wiener, a rather different approach was initiated, namely a study of wave-trains in the time domain as a quasi-stationary time series, ${ }^{47}$ and on this basis studies began in terms of autocorrelation and crosscorrelation which led to the first use of computers in neurology.

These first attempts were made on three different experimental computers at the Massachusetts Institute of Technology, each of which was a special-purpose digital computer designed for its own particular problem, far removed from phenomena of brain potentials.

Since then, of course, the utilization, as well as the development, of computers has been phenomenal. Spectacular change was heralded by the invention by Shockley and his colleagues ${ }^{40}$ in 1948 of the transistor; following this the bioscientist could in due time begin to welcome small but powerful special-purpose computers to his laboratory bench-computers made of solid-state components.

And now, as the age of the monster electronic computer fades to be replaced by the more compact transistorized models, yet another shrinkage reaches us from technology in the shape of integrated circuits. There had been an intermediate stage between the transistor, as originally invented, and a subsequent development which included resistors, capacitors and diodes as a complete circuit constructed on a silicon base and this development led directly to miniaturization.

For anyone who worked with the vacuum-tube computers of the early 1950s these miniaturized circuits seem miraculous as they result in exquisitely compact instruments for data-processing; circuits with as many as 100,000 components can be made to occupy only one square inch. The central processors of many commercial 


\section{Mary A. B. Brazier}

computers began to incorporate integrated circuits in the 1960 s, and one may predict that they will soon displace the magnetic core memory with which we now work.

For the medical scientist, from whose viewpoint this review is written, this can mean an immense facilitation of his research with bench-size, or even portable computers whose input and output devices he himself can operate in the laboratory or on the ward, even if he has no intimate understanding of the central processing unit.

The challenge remains: can the bioscientist progress at the speed of technological advance, for this is at an exponential rate? We have seen the abacus give way, after hundreds of years, to mechanical, hand-operated adding machines and, after another 250 years to mechanical multipliers and dividers. The cog-wheel did not give way to the electron tube until the 1940s, but by the 1950s the transistor had replaced the tube. Already in the 1960 s the integrated circuit commanded the field. What will the 70 s give us?

\section{REFERENCES}

1. ARLand, M., Pascal, Paris, Éditions à l'Enfant Poète, 1946.

2. BABbaGe, C., Ninth Bridgewater Treatise: a Fragment, 1838.

3. BABBAGE, C., Babbage's Calculating Engines, being a Collection of Papers relating to them; their History and Construction, London, Spon, 1889.

4. Béguin, A., Pascal par Lui-même, Paris, Éditions du Seuil, 1952.

5. Bollé, L., Bull. Soc. Encour. Indus. nat., 1895, 10, 989.

6. Catalogue Général des Collections du Conservatoire Royale des Arts et Métiers, Paris, 1818.

7. Descartes, R., Letter to Carcavi, dated June 1649. (Quoted in: L. Petit, Descartes et la Princesse Elisabeth, Paris, Éditions A-G Nizet, 1969.

8. Diderot, D., L'Encyclopédie ou Dictionnaire Raisonné des Sciences, des Arts et des Métiers, 1751, 1, 681-84, Suppl. 111., p. 619.

9. Dietsch, G., 'Fourier-Analyse von Elektrenkephalogrammen des Menschen', Pfliig. Arch. ges. Physiol., 1932, 230, 106-12.

10. Fleming, J. A., British Patent Specifications No. 24850, 16 November 1904.

11. Foster, J., Testimony before the Senate Committee on Armed Services, 1969. Reported by A. R. Laufer, in: The Sponsorship of Basic Research, Naval Research Reviews, 1970, 23, (2) 1-15.

12. Hariot, ThOMas, MSS. 6786 Folio 347. British Museum.

13. Hansch, M. G., Joannis Kepleri aliorumque epistolae, Leipzig, 1718, p. 683.

14. HeLmHOLTZ, H. vON, 'Messungen über den zeitlichen Verlauf der Zuchung animalischer Muskeln und die Fortpflanzungsgeschwindigkeit der Reizung in den Nerven', Arch. Anat. Physiol., 1850, 276-364.

15. HILlERIN DE BoIstisandeAu, in: Machines approuvées par l'Académie Royale des Sciences, 1735, 5, (1727-1731), p. 103.

16. Hoyau, L. A. D. (ed.), Bull. Soc. Encour. Indus. nat., 1822, 21, 355. (The calculating machine designed by Ch. X. Thomas of Colmar).

17. Humbert, P., Cet Effrayant Génie. L'Oeuvre Scientifique de Blaise Pascal, Paris, 1947.

18. Huygens, C., Oeuvres de Huygens, vol. 2. p. 451, The Hague, Société hollandaise des Sciences, 1950.

19. KEPLER, MSS Bd. 15 p. 229. Letter from W. Schickhard reproduced in: F. Hammer (ed.), Gesammelle Werke von J. Kepler. No. 975, 169-71, Munich, 1959.

20. KIlluRN, T., 'The University of Manchester high-speed digital computing machine', Nature, Lond., 1949, 164, 684-87.

21. LEE DE FOREST, Application made for a U.S. patent in October 1906.

22. LetBnIz, G. W., Opera Omnia, Geneva, 1768, vol. 3, No. 74, p. 413. 


\section{From Calculating Machines to Computers}

23. LÉPINE, in: Machines approuvées par l'Académie Royale des Sciences, 1735, 4(1720-1726), p. 131.

24. Martin, G., 'Machine Arithmétique de M. Pascal', in M. Gallon (ed.), Machines et Inventions approuvées par l'Académie Royale des Sciences. Faris, 1735, 4, 137-39.

25. MORLAND, S., The description and use of two arithmetick instruments together with a short treatise explaining and demonstrating the ordinary operations of arithmetick, London, 1673.

26. Morland, S., Machina Nova Cyclologica pro Multiplicationes, London, Printed by Moses Pitt at the White Hart, 1666.

27. National Museum of Sweden, Christina Queen of Sweden, 11th Exhibition of the Council of Europe, 1966, pp. 209-11.

28. D'Ocagne, M., Le Calcul Simplifié par les Procédés Mécaniques et Graphiques, Paris, Gauthier-Villars, 3rd ed., 1928, 205 pp.

29. Pascal, Blaise, Advis Necessaire, 1645. Quoted in: P. Humbert, Les Grands Ecrivains de la France: Blaise Pascal, Oeuvres I. Paris, 1923 (pp. 312 and 313).

30. Payen, J., 'Les exemplaires conservés de la machine de Pascal', Rev. Hist. Sci., 1963, 16, 161-78.

31. Pensées de M. Pascal sur la Religion et sur quelques autres sujets. Qui ont etté trouvées après sa mort parmy ses papiers. Paris, Guillaume Despree, 1669.

32. Perrault, C., Mémoires pour servir a l'Histoire des Animaux, Paris, Académie Royale des Sciences, 1671-1676.

33. Perrault, Claude, 'Abaque Rhabdologique inventé par M. Perrault', Machines et Inventions approuvées par l'Académie Royale des Sciences 1735, 1, (1666-1701), 55-58.

34. Perrault, Claude, Recueil de plusiers machines de nouvelle invention, Paris, Coignard, 1700.

35. Polkn, G., Miscellanea: hoc est machina arithmeticae ejusque usus descriptio, Venice, 1709, p. 27.

36. RoTH, D. D., Bull. Soc. Encour. Indust. nat., 1843, p. 411.

37. SchiUTZ, G., and ScheUTZ, E., Räkne-maskin, Ofversigt Vetensk. Akad. förhandlingar, Stockholm, 1860, 16, 391.

38. SeberT, H., Bull. Soc. Encour. Indus. nat., 1895, pp. 732 and 977.

39. Sellnng, E., Eine neue Rechenmachine, Berlin, 1887.

40. Shockiey, W., BardeEn, J. and BrattaIN, W. H., 'Electronic theory of the transistor', Science, 1948, 108, 678-79.

41. Staff of the Computation Laboratory, Harvard University. A Manual of Operation for the Automatic Sequence Controlled Calculator, Cambridge, Mass., Harvard University Press, 1946.

42. StzRn, A., Leipziger Literatur-Zeitung für 1814, p. 244, and Société des Sciences de Varsovie, 1818, 12, 106 (in Polish).

43. Taton, R., 'Sur l'invention de la machine arithmétique', Rev. Hist. Sci., 1963, 16, 139-60.

44. TAton, R. and Flad, J.-P., Le Calcul Mécanique, Paris, Presses Universitaires de France, 1963, 128 pp.

45. Thomas, Ch. X., 'Numero commémoratif du Centenaire de l'Invention, par Thomas de Colmar, de la première machine à calculer industrielle', Bull. Soc. Encour. Indus. nat., vol. 132, no. 5, Paris, 1920.

46. WALter, W. GREY, 'An automatic low frequency analyser', Electronic Eng., 1943, 16, 9-13.

47. WIENER, N., Extrapolation, Interpolation, and Smoothing of Stationary Time Series, New York, J. Wiley and Technology Press. Mass. Inst. Technol., 1957, 163 pp.

48. WIIKEs, M. V., and RENWICK, W., 'The EDSAC_an electronic calculating machine', J. sci. Instr., 1949, 26, 385-91. 